\title{
Determination of some conditions for hairy root induction in soybean by Agrobacterium rhizogenes
}

\author{
Linh B. Ton ${ }^{1}$, Vu X. Le ${ }^{1}$, Trinh T. T. Ngo ${ }^{2}, \&$ Phong V. Nguyen ${ }^{1 *}$ \\ ${ }^{1}$ Department of Biotechnology, Nong Lam University, Ho Chi Minh City, Vietnam \\ ${ }^{2}$ The Youth Scientific and Technological Promotion Center, Ho Chi Minh City, Vietnam
}

\begin{abstract}
ARTICLE INFO
Research paper

Received: December 26, 2017

Revised: March 11, 2018

Accepted: March 27, 2018

Keywords

Agrobacterium rhizogenes

Cotyledon

Hairy root

Soybean

Transformation

\section{${ }^{*}$ Corresponding author}

Nguyen Vu Phong

Email: nvphong@hcmuaf.edu.vn
\end{abstract}

\begin{abstract}
This study was conducted to determine some conditions for transformation via Agrobacterium rhizogenes on soybean cultivars HLDN29 and DT84. Cotyledon explants were more efficient in hairy root induction compared with hypocotyl explants in both cultivars of soybean. The highest root induction rate and average root number were observed in HLDN29 explants infected with ATCC11325 and ATCC15834 strains (approx. 96\% - 100\% and 8 roots per explant) and in DT84 explants infected with ATCC15834. Six to eight day - old cotyledonary leaves after sowing were optimal and appropriate for hairy root induction. Direct inoculation and immersion methods showed no significant difference in root induction rate and average root number in both HLDN29 and DT84 cultivars. Transgenic root lines were identified based on $\mathrm{PCR}$ analysis with vir $\mathrm{D}$ và rol $\mathrm{C}$ sequences specific primers.
\end{abstract}

Cited as: Ton, L. B., Le, V. X., Ngo, T. T. T., \& Nguyen, P. V. (2018). Determination of some conditions for hairy root induction in soybean by Agrobacterium rhizogenes. The Journal of Agriculture and Development 17(4), 86-93. 


\title{
Xác định một số điều kiện thích hợp cảm ứng tạo rễ tóc đậu nành sử dụng vi khuẩn Agrobacterium rhizogenes
}

\author{
Tôn Bảo Linh ${ }^{1}$, Lê Xuân Vũ ${ }^{1}$, Ngô Thị Tú Trinh ${ }^{2} \&$ Nguyễn Vũ Phong ${ }^{1 *}$ \\ ${ }^{1}$ Bộ Môn Công Nghệ Sinh Học, Trường Đại Học Nông Lâm TP. Hồ Chí Minh, TP. Hồ Chí Minh \\ ${ }^{2}$ Trung Tâm Phát Triển Khoa Học và Công Nghệ Trẻ, TP. Hồ Chí Minh
}

\author{
THÔNG TIN BÀI BÁO \\ Bài báo khoa học \\ Ngày nhận: 26/12/2017 \\ Ngày chỉnh sửa: 11/03/2018 \\ Ngày chấp nhận: 27/03/2018 \\ Từ khóa \\ Agrobacterium rhizogenes \\ Chuyển gen \\ Đậu nành \\ Lá mầm \\ Rễ tóc \\ *Tác giả liên hệ \\ Nguyễn Vũ Phong \\ Email: nvphong@hcmuaf.edu.vn
}

\section{TÓM TẮT}

Nghiên cứu nhằm xác định một số điều kiện thích hợp cho chuyển gen bằng vi khuẩn Agrobacterium rhizogenes ở hai giống đậu nành HLĐN29 và DT84. Ở cả hai giống đậu nành, mẫu lá mầm cảm ứng tạo rễ tốt hơn so với trụ hạ diệp. Ở giống đậu nành HLĐN29, 96 $100 \%$ mẫu tạo rễ khi lây nhiễm với chủng vi khuẩn ATCC11325 và ATCC15834, số rễ trung bình khoảng 8 rễ/mẫu. Đối với giống đậu nành DT84, chỉ có chủng vi khuẩn ATCC15834 cho hiệu quả tạo rễ tốt nhất. Sử dụng lá mầm đậu nành 6 - 8 ngày sau khi gieo cho hiệu quả tạo rễ tốt nhất và thuận tiện trong thao tác. Hai cách lây nhiễm trực tiếp và ngâm mẫu cho tỉ lệ mẫu tạo rễ và số rễ trung bình tương đương nhau trên cả hai giống đậu nành HLĐN29 và DT84. Rễ chuyển gen được xác định thông qua phân tích PCR sử dụng cặp primer đặc hiệu cho gen $\operatorname{vir} \mathrm{D}$ và $\operatorname{rol} \mathrm{C}$.

\section{1. Đặt Vấn Đề}

Đậu nành (Glycine max L. Merrill) là cây công nghiệp ngắn ngày có giá trị dinh dưỡng cao đối với người và vật nuôi, có tầm quan trọng về mặt kinh tế đứng sau lúa mì, lúa nước và ngô (Tran, 2007; Homrich \& ctv., 2012). Vì vậy, các nghiên cứu nhằm cải thiện chất lượng và năng suất đậu nành rất được chú trọng. Hiện nay, đậu nành biến đổi gen đang được trồng rộng rãi trên khắp thế giới và chiếm $78 \%$ tổng diện tích đậu nành toàn cầu (ISAAA, 2016). Ở Việt Nam, đậu nành là một trong ba loại cây trồng được ưu tiên trong các nghiên cứu chuyển gen. Các mục tiêu chọn tạo giống đậu nành gồm năng suất cao, kháng bệnh và chống chịu tốt với các điều kiện bất lợi (Krishnan, 2005). Tuy nhiên, việc tạo ra các dòng đậu nành chuyển gen gặp nhiều hạn chế do phản ứng của kiểu gen với điều kiện tái sinh và các tác nhân khác (Kereszt \& ctv., 2007; Cao \& ctv., 2009).
Chuyển gen thông qua vi khuẩn Agrobacterium là phương pháp được sử dụng phổ biến trong chuyển gen thực vật (Ozyigit \& ctv., 2013). Trong đó, tạo rễ đậu nành chuyển gen bằng A.rhizogenes là một công cụ hiệu quả trong nghiên cứu chức năng gen (Homrich \& ctv., 2012). Vi khuẩn A.rhizogenes gây bệnh rễ tóc (hairy root) trên cây, tương tự như bệnh khối u gây ra bởi A.tumefaciens. Rễ tóc nuôi cấy phát triển nhanh chóng theo chiều xiên và phân nhánh cao trên môi trường không có chất điều hòa sinh trưởng (Collier \& ctv., 2005).

Trên đậu nành, rễ tóc thường được sử dụng để biểu hiện các promoter (Hernandez-Garcia \& ctv., 2010), nhân nuôi tuyến trùng bào nang (Cho \& ctv., 2000), nghiên cứu tổ chức cộng sinh vùng rễ (Hayashi \& ctv., 2010) và các tương tác gây bệnh vùng rễ (Li \& ctv., 2010), ngoài ra chúng còn được biểu hiện các gen RNAi im lặng (Subramanian \& ctv., 2005). Hiệu quả tạo rễ tóc trên đậu nành thay đổi tùy vào kiểu gen đậu nành và 
chủng vi khuẩn sử dụng. Nghiên cứu này nhằm đánh giá ảnh hưởng của nguồn vật liệu dùng để chuyển gen, độ tuổi của mẫu và cách lây nhiễm đến hiệu quả tạo rễ tóc ở đậu nành.

\section{Vật Liệu và Phương Pháp Nghiên Cứu}

\subsection{Chuẩn bị vi khuẩn}

Vi khuẩn A.rhizogenes dạng tự nhiên không mang plasmid tái tổ hợp gồm các chủng ICPB (International Collection of Phytopathogenic Bacteria) TR7, 19812, ATCC11325, ATCC15834 do TS. Nguyễn Vũ Phong, Bộ môn Công Nghệ Sinh học Trường Đại học Nông Lâm Tp. Hồ Chí Minh cung cấp; chủng C25 do TS. Nguyễn Như Nhứt, Công ty TNHH Gia Tường (Bình Dương) cung cấp.

Các chủng A.rhizogenes được cấy ria trên môi trường YEP (Olhoft \& ctv., 2003). Sau 48 giờ chọn khuẩn lạc đơn tăng sinh trong môi trường YEP lỏng, ở nhiệt độ phòng, lắc 150 rpm trong 12 - 15 giờ. Khi giá trị OD600 của dịch khuẩn đạt 0,5 - 1,0 thì tiến hành ly tâm thu sinh khối vi khuẩn tốc độ $3.500 \mathrm{rpm}$ trong 20 phút ở $4^{0} \mathrm{C}$. Huyền phù vi khuẩn trong môi trường LCCM (AL-Yozbaki \& ctv., 2015) có bổ sung acetosyringone $200 \mu \mathrm{M}$. Sử dụng dịch huyền phù vi khuẩn để lây nhiễm mẫu đậu nành.

\subsection{Chuẩn bị mẫu đậu nành}

Giống đậu nành HLĐN 29 cung cấp bởi Trung tâm Nghiên cứu Thực nghiệm Nông nghiệp Hưng Lộc thuộc Viện Khoa học Kỹ thuật Nông nghiệp miền Nam và giống đậu nành DT84 của Công ty cổ phần Giống cây trồng miền Nam được sử dụng trong nghiên cứu.

Các hạt đậu nành có kích thước lớn và đồng đều được khử trùng bề mặt bằng khí chlorine trong khoảng 14 - 18 giờ (Olhoft \& ctv., 2007). Sau đó, gieo hạt đậu nành đã khử trùng vào chai thủy tinh $500 \mathrm{~mL}$ chứa $100 \mathrm{~mL}$ môi trường $\mathrm{B} 5$ (Gamborg \& ctv., 1968) bổ sung sucrose (3\%), agar $(0,8 \%)$, pH 5,8. Mỗi chai cấy 10 hạt đậu nành, đặt dưới điều kiện chiếu sáng 16 giờ/ngày ở $25 \pm 1^{0} \mathrm{C}$. Sau $2-10$ ngày, sử dụng lá mầm và trụ hạ diệp đậu nành để lây nhiễm vi khuẩn.

\subsection{Lây nhiễm vi khuẩn và cảm ứng tạo rễ}

Mẫu đậu nành được lây nhiễm A.rhizogenes dựa trên qui trình của AL-Yozbaki \& ctv. (2015).
Dùng lưỡi dao mổ (số 11) tạo vết thương ở mặt dưới lá mầm (3 vết thương/lá mầm, chiều dài vết thương khoảng $0,7 \mathrm{~cm}$ ), cắt ngang trụ hạ diệp thành đoạn có chiều dài khoảng $2,5 \mathrm{~cm}$ và tạo vết thương theo chiều dài mẫu, sau đó ngâm mẫu trong dịch khuẩn 15 phút. Thấm khô bề mặt mẫu bằng khăn giấy đã khử trùng, chuyển mẫu trên đĩa môi trường CCM có bổ sung acetosyringone $200 \mu \mathrm{M}$ và đặt trong tối ở $25^{\circ} \mathrm{C}$ trong 3 ngày. Sau giai đoạn đồng nuôi cấy (co-cultivation), loại vi khuẩn bằng cách rửa mẫu 2 lần bằng mồi trường MXB lỏng (LMXB) và ngâm trong môi trường LMXB có bổ sung cefotaxime $500 \mathrm{mg} / \mathrm{L}$ và carbenicillin $400 \mathrm{mg} / \mathrm{L}$, lắc $100 \mathrm{rpm}$ trong 30 phút. Mẫu được thấm khô bề mặt, đặt trên môi trường MXB (AL-Yozbaki \& ctv., 2015) có bổ sung cefotaxime $500 \mathrm{mg} / \mathrm{L}$, ở $25^{\circ} \mathrm{C}$ và chiếu sáng 16 giờ/ngày. Đối với cách lây nhiễm vi khuẩn trực tiếp, nhúng lưỡi dao vào dịch khuẩn sau đó tạo vết thương trên mẫu. Mẫu sau khi lây nhiễm vi khuẩn được duy trì ở cùng điều kiện như trường hợp ngâm mẫu.

Các yếu tố quan trọng liên quan đến kết quả tạo rễ tóc trên đậu nành được khảo sát gồm sự phù hợp giữa 5 chủng A.rhizogenes và loại mẫu (lá mầm và trụ hạ diệp) đậu nành, độ tuổi mẫu (2 - 10 ngày) và cách thức lây nhiễm (lây nhiễm trực tiếp và ngâm mẫu). Sau khi lây nhiễm 14 ngày ghi nhận tỉ lệ mẫu tạo rễ (\%) và số rễ trung bình của các mẫu tạo rễ. Ở các thí nghiệm, mỗi nghiệm thức được lặp lại ba lần, mỗi lần sử dụng 10 hạt. Mẫu lá mầm và trụ hạ diệp sau khi lây nhiễm vi khuẩn được cấy trên đĩa môi trường đường kính $10 \mathrm{~cm}, 10$ mẫu/đĩa. Hạt đậu nành mới gieo được qui ước là 0 ngày tuổi.

\subsection{Phân tích PCR}

Các dòng rễ tóc được tách khỏi mẫu và tăng sinh trên môi trường B5 trong khoảng 1 tháng. Sau đó, DNA tổng số của rễ giả định chuyển gen và rễ không chuyển gen được tách chiết bằng kit (GeneJET, Thermo Fisher Scientific). Tách chiết DNA plasmid từ dịch vi khuẩn tăng sinh 48 giờ bằng ISOLATE II Plasmid Mini Kit (Bioline). Sử dụng kỹ thuật PCR với các cặp primer đặc hiệu cho vi khuẩn A.rhizogenes và đậu nành (Bảng 1 ) để xác định rễ chuyển gen. Mỗi phản ứng PCR (25 $\mu \mathrm{L}$ ) gồm 12,5 $\mu \mathrm{L}$ MyTaq Mix (Bioline), DNA khuôn, primer xuôi và primer ngược $(0,8 \mu \mathrm{M}$ mỗi primer), nước khử ion tiệt trùng. Chu kì nhiệt phản ứng khuếch đại gồm giai đoạn tiền biến tính 
Bảng 1. Các trình tự primer sử dụng trong nghiên cứu

\begin{tabular}{|c|c|c|c|}
\hline Gen & Trình tự primer & $\begin{array}{l}\text { Kích thước } \\
\text { sản phẩm } \\
\text { (bp) }\end{array}$ & Tài liệu \\
\hline Golgin 84 & $\begin{array}{l}\text { F: 5'-TTG GAC AAG GAG AGA CTC CAC -3' } \\
\text { R: 5'-TGC GAG GCT ACG AAA ACT TC -3' }\end{array}$ & 121 & $\begin{array}{l}\text { Marcolino-Gomes } \\
\text { \& ctv., } 2015\end{array}$ \\
\hline RolC & $\begin{array}{l}\text { F: 5'-TAA CAT GGC TGA AGA CGA CC-3' } \\
\text { R: 5'-AAA CTT GCA CTC GCC ATG CC-3' }\end{array}$ & 534 & $\begin{array}{l}\text { Fattahi \& ctv., } \\
2013\end{array}$ \\
\hline $\operatorname{Vir} \mathrm{D}$ & $\begin{array}{l}\text { F:5' ATG TGG CAA GGC AGT AAG CCCA-3' } \\
\text { R: 5'- GGA GTC TTT CAG CAG GAG CAA-3' }\end{array}$ & 438 & $\begin{array}{l}\text { Fattahi \& ctv., } \\
2013\end{array}$ \\
\hline
\end{tabular}

$93^{0} \mathrm{C}$ trong 3 phút, 35 chu kì khuếch đại gồm giai đoạn biến tính ở $95^{\circ} \mathrm{C}$ trong 25 giây, bắt cặp ở $57^{\circ} \mathrm{C}$ trong 25 giây và kéo dài ở $72^{0} \mathrm{C}$ trong 45 giây. Sản phẩm khuếch đại được hoàn thiện ở $72^{0} \mathrm{C}$ trong 45 giây.

Sản phẩm PCR được bổ sung thuốc nhuộm GelRed (TBR, Việt Nam) và điện di trên gel agarose $2 \%$ (Bioline) ở hiệu điện thế $80 \mathrm{~V}$ trong 35 phút, sử dụng dung dịch đệm TBE 0,5X (Bioline). Sau khi điện di, đọc kết quả dưới đèn UV. Mẫu rễ cho kết quả $\mathrm{PCR}$ dương tính với gen $r o l \mathrm{C}$ và âm tính với gen vir $\mathrm{D}$ là mẫu được chuyển gen thành công và được sử dụng làm nguồn vật liệu ban đầu để nhân sinh khối rễ đậu nành. Gen Golgin 84 là gen thường trực ở đậu nành (Marcolino-Gomes \& ctv., 2015).

\subsection{Xử lý số liệu}

Số liệu thu thập được xử lí thống kê, đọc kết quả dựa vào phân tích ANOVA, bảng trung bình và bảng so sánh khác biệt giữa các nghiệm thức theo trắc nghiệm phân hạng (LSD).

\section{Kết Quả và Thảo Luận}

\subsection{Sự phù hợp giữa chủng A.rhizogenes và loại mẫu trong cảm ứng tạo rễ ở đậu nành}

Tỉ lệ mẫu tạo rễ và số rễ trung bình ở các nghiệm thức sau giai đoạn loại bỏ vi khuẩn 14 ngày được thể hiện ở Bảng 2 và Bảng 3 . Tỉ lệ mẫu tạo rễ và số rễ trung bình ở lá mầm cao hơn ở trụ hạ diệp và khác biệt rất có ý nghĩa về mặt thống kê. Tuy nhiên, không có sự khác biệt đáng kể về tỉ lệ mẫu lá mầm tạo rễ. Bảng 3 cho thấy ở giống HLĐ29, mẫu lá mầm lây nhiễm với chủng ATCC11325, ATCC15834 có số rễ trung bình cao nhất và khác biệt rất có ý nghĩa so với các nghiệm thức còn lại và đối chứng. Trong khi đó, chủng ATCC 15834 cho hiệu quả tạo rễ cao nhất trên mẫu lá mầm giống DT84. Nghiên cứu của AL-Yozbaki \& ctv. (2015) cũng cho thấy tỉ lệ tạo rễ thấp ở trụ hạ diệp $(16 / 25)$ so với lá mầm $(20 / 26)$.

Kết quả tạo rễ ở các nghiệm thức sử dụng mẫu trụ hạ diệp ở cả hai giống đậu nành tương đương nhau và không khác biệt so với đối chứng, ngoại trừ nghiệm thức sử dụng ICPB TR7 ở giống DT84 với số rễ trung bình thấp nhất $(0,6$ rễ (Hình 1). Bên cạnh đó, kết quả phân tích thống kê thể hiện sự tương tác giữa loại mẫu và chủng vi khuẩn ở cả hai giống đậu nành. Điều đó cho thấy sự phù hợp giữa chủng A.rhizogenes và mẫu lây nhiễm có liên quan với hiệu quả cảm ứng tạo rễ trên đậu nành.

Trong nghiên cứu tương tự của Savka \& ctv. (1990), tỉ lệ mẫu cảm ứng tạo rễ của 10 kiểu gen đậu nành sử dụng A.rhizogenes K599 (chủng cucumopine) là $37 \%$. Ở chủng mannopine-type 8196, tî lệ này là $3 \%$ trên 4 kiểu gen đậu nành và chủng agropine 1855 và $\mathrm{A} 4$ có tỉ lệ mẫu tạo rễ thấp nhất (1\%). Mẫu trụ hạ diệp tuy xuất hiện rễ sau khi lây nhiễm với tất cả các chủng A.rhizogenes trong khảo sát, nhưng không phải là rễ tóc có khả năng tổng hợp opine.

\section{2. Ảnh hưởng tuổi của mẫu đậu nành đến khả năng cảm ứng tạo rễ tóc}

Tuổi của mẫu cấy là một yếu tố quan trọng trong thí nghiệm chuyển gen (Tazeen và Mirza, 2004). Hiệu quả chuyển gen với Agrobacterium liên quan chặt chẽ với độ tuổi và cân bằng nội tiết tố của vật chủ (Karmarkar \& ctv., 2001). Khả năng tạo rễ của lá mầm đậu nành $2,4,6,8$ và 10 ngày tuổi khi lây nhiễm chủng ATCC15834 được ghi nhận ở Bảng 4. 
Bảng 2. Tỉ lệ (\%) mẫu lá mầm và trụ hạ diệp tạo rễ (A) sau lây nhiễm với các chủng A.rhizogenes khác nhau (B)

\begin{tabular}{ccccccc}
\hline Chủng & \multicolumn{3}{c}{ HLĐN29 } & \multicolumn{3}{c}{ DT84 } \\
\cline { 2 - 7 } $\begin{array}{c}\text { A.rhizogenes } \\
(\mathrm{B})\end{array}$ & $\begin{array}{c}\text { Lá mầm } \\
(\mathrm{A})\end{array}$ & $\begin{array}{c}\text { Trụ hạ diệp } \\
(\mathrm{A})\end{array}$ & $\begin{array}{c}\text { Trung bình } \\
(\mathrm{B})\end{array}$ & $\begin{array}{c}\text { Lá mầm } \\
(\mathrm{A})\end{array}$ & $\begin{array}{c}\text { Trụ hạ diệp } \\
(\mathrm{A})\end{array}$ & $\begin{array}{c}\text { Trung bình } \\
(\mathrm{B})\end{array}$ \\
\hline ATCC11325 & 96,7 & 20,0 & 58,3 & 90,0 & 20,0 & $55,0^{\mathrm{ab}}$ \\
ATCC15834 & 100 & 40,0 & 70,0 & 98,3 & 40,0 & $69,2^{\mathrm{a}}$ \\
19812 & 96,7 & 43,3 & 70,0 & 90,0 & 20,0 & $55,0^{\mathrm{ab}}$ \\
C25 & 96,7 & 53,3 & 75,0 & 93,3 & 16,7 & $55,0^{\mathrm{ab}}$ \\
ICPB TR7 & 96,7 & 60,0 & 78,3 & 95,0 & 23,3 & $59,1^{\mathrm{ab}}$ \\
Đối chứng & 98,3 & 23,3 & 60,8 & 80,0 & 13,3 & $46,7^{\mathrm{b}}$ \\
Trung bình (A) & 96,7 & 40,0 & & 91,1 & 22,2 & \\
& $\mathrm{~F}_{\mathrm{A}}=221^{* *}$ & $\mathrm{~F}_{\mathrm{AB}}=2,4^{\mathrm{ns}}$ & $\mathrm{F}_{\mathrm{A}}=414^{* *}$ & $\mathrm{~F}_{\mathrm{AB}}=0,32^{\mathrm{ns}}$ \\
& $\mathrm{F}_{\mathrm{B}}=1,80^{\mathrm{ns}}$ & $\mathrm{CV}(\%)=18,5$ & $\mathrm{~F}_{\mathrm{B}}=5,20^{* *}$ & $\mathrm{CV}(\%)=13,7$ \\
\hline
\end{tabular}

Bảng 3. Số rễ được tạo thành từ các loại mẫu đậu nành in vitro $(\mathrm{A})$ sau khi lây nhiễm các chủng A.rhizogenes khác nhau $(\mathrm{B})^{1}$

\begin{tabular}{ccccccc}
\hline $\begin{array}{c}\text { Chủng } \\
\text { A.rhizogenes } \\
(\mathrm{B})\end{array}$ & $\begin{array}{c}\text { Lá mầm } \\
(\mathrm{A})\end{array}$ & $\begin{array}{c}\text { Trụ̣ } \\
\text { hạ diệp } \\
(\mathrm{A})\end{array}$ & $\begin{array}{c}\text { Trung } \\
\text { bình } \\
(\mathrm{B})\end{array}$ & $\begin{array}{c}\text { Lá mầm } \\
(\mathrm{A})\end{array}$ & $\begin{array}{c}\text { Trụ } \\
\text { hạ diệp } \\
(\mathrm{A})\end{array}$ & $\begin{array}{c}\text { Trung } \\
\text { bình } \\
(\mathrm{B})\end{array}$ \\
\hline ATCC11325 & $8,27^{\mathrm{a}} \pm 0,57$ & $3,17^{\mathrm{c}} \pm 0,62$ & $5,72^{\mathrm{a}}$ & $4,60^{\mathrm{c}} \pm 0,38$ & $1,57^{\mathrm{d}} \pm 0,45$ & $3,08^{\mathrm{bc}}$ \\
ATCC15834 & $8,23^{\mathrm{a}} \pm 0,84$ & $3,33^{\mathrm{c}} \pm 0,51$ & $5,78^{\mathrm{a}}$ & $6,32^{\mathrm{a}} \pm 0,10$ & $1,97^{\mathrm{d}} \pm 0,25$ & $4,14^{\mathrm{a}}$ \\
19812 & $5,34^{\mathrm{b}} \pm 0,72$ & $2,98^{\mathrm{c}} \pm 0,87$ & $4,16^{\mathrm{b}}$ & $5,45^{\mathrm{b}} \pm 0,22$ & $1,27^{\mathrm{d}} \pm 0,15$ & $3,36^{\mathrm{b}}$ \\
C25 & $6,30^{\mathrm{b}} \pm 0,24$ & $2,92^{\mathrm{c}} \pm 0,82$ & $4,61^{\mathrm{ab}}$ & $4,65^{\mathrm{c}} \pm 0,23$ & $1,43^{\mathrm{d}} \pm 0,87$ & $2,65^{\mathrm{c}}$ \\
ICPB TR7 & $5,39^{\mathrm{b}} \pm 0,93$ & $2,32^{\mathrm{c}} \pm 0,74$ & $3,85^{\mathrm{b}}$ & $4,70^{\mathrm{c}} \pm 0,45$ & $0,60^{\mathrm{e}} \pm 0,17$ & $3,47^{\mathrm{b}}$ \\
Đối chứng & $4,91^{\mathrm{b}} \pm 0,27$ & $2,17^{\mathrm{c}} \pm 0,62$ & $3,54^{\mathrm{b}}$ & $5,20^{\mathrm{b}} \pm 0,35$ & $1,73^{\mathrm{d}} \pm 0,06$ & $3,47^{\mathrm{b}}$ \\
Trung bình (A) & 6,41 & 2,81 & & 5,15 & 1,43 & \\
& $\mathrm{~F}_{\mathrm{A}}=159^{* *}$ & $\mathrm{~F}_{\mathrm{AB}}=2,70^{*}$ & $\mathrm{~F}_{\mathrm{A}}=866^{* *}$ & $\mathrm{~F}_{\mathrm{AB}}=3,21^{*}$ & \\
& $\mathrm{~F}_{\mathrm{B}}=7,45^{* *}$ & $\mathrm{CV}(\%)=18,51$ & $\mathrm{~F}_{\mathrm{B}}=10,6^{* *}$ & $\mathrm{CV}(\%)=11,5$ \\
\hline
\end{tabular}

${ }^{1}$ Số liệu được trình bày dạng Trung bình $\pm \mathrm{SD}$ (Độ lệch chuẩn); CV: hệ số biến thiên; các kí tự a, b, $\mathrm{c}$ thể hiện sự khác biệt về mặt thống kê; ${ }^{*}$ sự khác biệt có ý nghĩa $(P<0,05)$; ${ }^{* *}$ sự khác biệt rất có ý nghĩa $(P<0,01)$.

Bảng 4. Số rễ tạo thành và tỉ lệ tạo rễ của lá mầm đậu nành ở các ngày tuổi khác nhau ${ }^{1}$

\begin{tabular}{ccccc}
\hline \multirow{2}{*}{ Ngày tuổi } & \multicolumn{2}{c}{ HLĐN29 } & & \multicolumn{3}{c}{ DT84 } \\
& $5,32 \pm 0,95$ & Tî̉ lệ mẫu tạo rễ $(\%)$ & Số rễ & Tỉ lệ mẫu tạo rễ $(\%)$ \\
\hline 2 & $5,65 \pm 1,10$ & 100,00 & $3,33^{b} \pm 1,58$ & 93,33 \\
4 & $6,70 \pm 0,95$ & 93,33 & $4,67^{b} \pm 1,99$ & 95,00 \\
6 & $8,39 \pm 1,49$ & 90,67 & $5,92^{a b} \pm 0,94$ & 91,67 \\
8 & $5,93 \pm 0,57$ & 88,33 & $8,33^{a} \pm 0,46$ & 91,67 \\
10 & $\mathrm{CV}(\%)=17,5 ;$ & $\mathrm{CV}(\%)=2,98 ;$ & $5,40^{a b} \pm 0,17$ & 88,33 \\
& $\mathrm{~F}=3,60^{\mathrm{ns}}$ & $\mathrm{F}=1,95^{\mathrm{ns}}$ & $\mathrm{F}=6,65^{* *}$ & $\mathrm{CV}(\%)=3,32 ;$ \\
& $\mathrm{F}=0,49^{\text {ns }}$ \\
\hline
\end{tabular}

${ }^{1}$ Số liệu được trình bày dạng Trung bình $\pm \mathrm{SD}$ (Độ lệch chuẩn); CV: hệ số biến thiên; các kí tự a, b, $\mathrm{c}$ thể hiện sự khác biệt về mặt thống kê; * sự khác biệt có ý nghĩa $(P<0,05) ;{ }^{* *}$ sự khác biệt rất có ý nghĩa $(P<0,01)$.

Kết quả cho thấy ở giống HLĐN29 số rễ trung bình và tỉ lệ mẫu tạo rễ của lá mầm từ 2 - 10 ngày tuổi không khác biệt về mặt thống kê. Trong đó, mẫu 10 ngày tuổi có tỉ lệ tạo rễ là thấp nhất. Ở giống DT84, tỉ lệ mẫu tạo rễ của lá mầm ở các ngày tuổi khác nhau không khác nhau về mặt thống kê, tuy nhiên số rễ trung bình có sự khác biệt đáng kể. Số rễ trung bình có xu hướng tăng đối với mẫu từ $2-8$ ngày sau khi gieo hạt và có xu hướng giảm từ ngày thứ 10 . Ở cả hai giống 
Bảng 5. Số rễ trung bình và tỉ lệ tạo rễ của mẫu lá mầm đậu nành sau khi lây nhiễm A.rhizogenes theo hai cách khác nhau ${ }^{1}$

\begin{tabular}{ccccc}
\hline \multicolumn{3}{c}{ HLĐN29 } & \multicolumn{2}{c}{ DT84 } \\
\hline Cách lây nhiễm & Số rễ $( \pm \mathrm{SD})$ & Tỉ lệ mẫu tạo rễ $(\%)$ & Số rễ $( \pm \mathrm{SD})$ & Tỉ lệ mẫu tạo rễ $(\%)$ \\
\hline Trực tiếp & $8,74^{\mathrm{a}} \pm 1,47$ & $98,3^{\mathrm{a}}$ & $7,07^{\mathrm{a}} \pm 0,11$ & $95,0^{\mathrm{a}}$ \\
ĐC1 & $3,79^{\mathrm{b}} \pm 0,55$ & $70,0^{\mathrm{c}}$ & $5,28^{\mathrm{b}} \pm 0,03$ & $78,3^{\mathrm{b}}$ \\
Ngâm mẫu & $6,68^{\mathrm{a}} \pm 1,15$ & $91,7^{\mathrm{ab}}$ & $7,26^{\mathrm{a}} \pm 0,27$ & $91,7^{\mathrm{a}}$ \\
ĐC2 & $4,15^{\mathrm{b}} \pm 0,21$ & $71,7^{\mathrm{bc}}$ & $4,54^{\mathrm{c}} \pm 0,19$ & $76,7^{\mathrm{b}}$ \\
& $\mathrm{CV}(\%)=14,1 ;$ & $\mathrm{CV}(\%)=13,4 ;$ & $\mathrm{CV}(\%)=2,88 ;$ & $\mathrm{CV}(\%)=3,57 ;$ \\
& $\mathrm{F}=24,07^{* *}$ & $\mathrm{~F}=6,76^{*}$ & $\mathrm{~F}=177,43^{* *}$ & $\mathrm{~F}=6,99^{*}$ \\
\hline
\end{tabular}

${ }^{1} \mathrm{SD}$ (Độ lệch chuẩn); CV: hệ số biến thiên; các kí tự $\mathrm{a}, \mathrm{b}, \mathrm{c}$ thể hiện sự khác biệt về mặt thống kê; * sự khác biệt có ý nghĩa $(P<0,05) ;{ }^{* *}$ sự khác biệt rất có ý nghĩa $(\dot{P}<0,01)$.
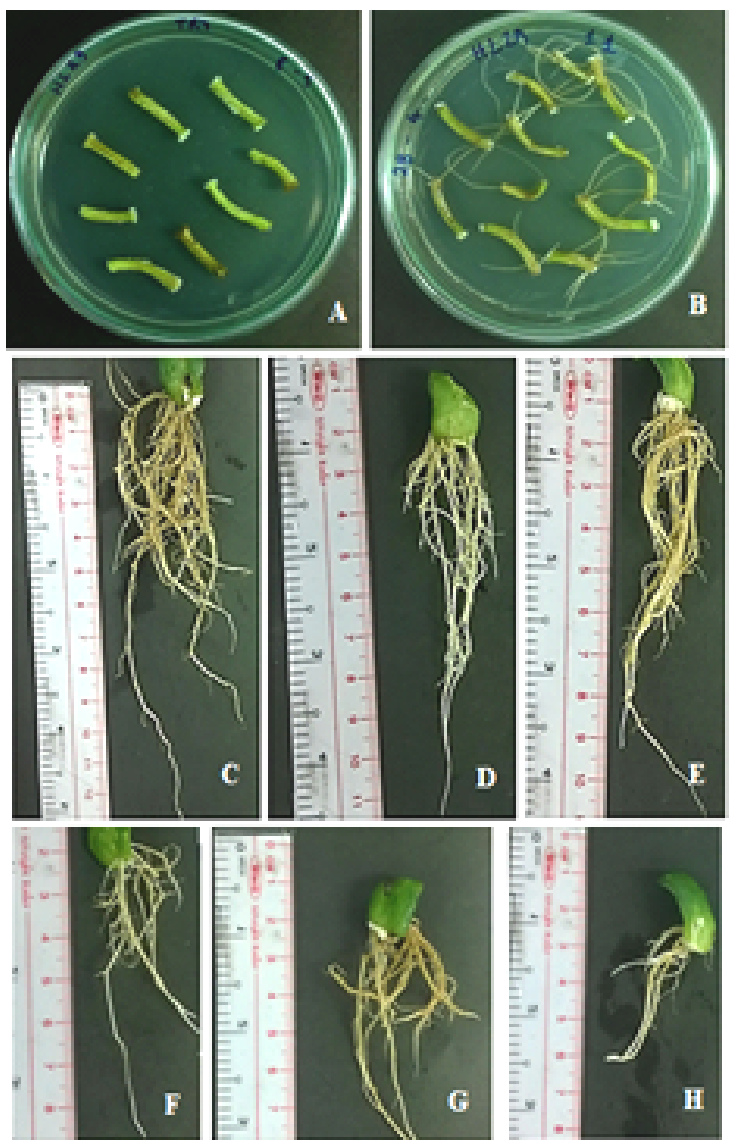

Hình 1. Lá mầm và trụ hạ diệp đậu nành HLĐ29 sau khi lây nhiễm A.rhizogenes 16 ngày trên môi trường MXB bổ sung cefotaxime $500 \mathrm{mg} / \mathrm{L}$.

(A) Mẫu trụ hạ diệp lây nhiễm với chủng ICBP TR7;

(B) ATCC11325; Lá mầm đậu nành sau khi lây nhiễm với các chủng (C) ATCC15834; (D) ATCC11325; (E) C25; (F) 19812; (G) ICPB TR7; (H) Đối chứng không lây nhiễm.

đậu nành, hầu hết các mẫu đều cảm ứng tạo rễ từ 7 - 10 ngày sau khi lây nhiễm vi khuẩn. Kết quả này cũng tương tự kết quả nghiên cứu của Cao \& ctv. (2009). Cụ thể, thí nghiệm xác định ảnh hưởng của tuổi mẫu đến quá trình chuyển gen trên đậu nành ex vitro sử dụng A.rhizogenes cho thấy mẫu đậu nành từ $3-8$ ngày tuổi đều tạo rễ sau khi lây nhiễm vi khuẩn từ $8-9$ ngày; chồi đậu nành 9 ngày sau khi gieo hạt có tỉ lệ mẫu tạo rễ thấp hơn so với mẫu 3 - 7 ngày, tuy nhiên sự khác biệt không có ý nghĩa về mặt thống kê. AL-Yozbaki \& ctv. (2015) sử dụng lá mầm đậu nành từ 7 - 10 ngày sau khi gieo hạt để tạo rễ tóc sử dụng A.rhizogenes R1000.

Chồi đậu nành sử dụng chất dinh dưỡng dự trữ trong hai lá mầm để tăng trưởng, do đó từ khi hạt nảy mầm, chất dinh dưỡng trong hai lá mầm sẽ giảm dần. Hiệu quả về mặt thời gian và cảm ứng tạo rễ cũng phụ thuộc vào độ tuổi mẫu. Mẫu ở giai đoạn sớm thường được khuyến khích sử dụng (Cao \& ctv., 2009). Bên cạnh đó, ở giai đoạn trên 9 ngày tuổi, lượng chất dinh dưỡng sẽ thấp hơn so với lá mầm ở giai đoạn sớm. Hạt đậu nành 2 ngày sau khi gieo bắt đầu trương to, hai lá mầm mới nứt ra và vẫn còn bọc trong vỏ hạt. Từ ngày thứ 4 , lá mầm đậu nành chuyển từ màu vàng sang màu xanh lá. Từ ngày thứ 6 trở đi, lớp vỏ hạt mới bắt đầu tách ra (Hình 2). Do đó trong thực tế, khi xử lí mẫu để lây nhiễm, sử dụng hạt đậu nành từ ngày thứ 6 trở đi tạo thuận lợi trong thao tác, ít làm tổn thương mẫu khi tách vỏ hạt và rút ngắn thời gian thực hiện giai đoạn này. Vì thế hạt đậu nành 6 - 8 ngày sau gieo là mẫu thích hợp để cảm ứng tạo rễ sử dụng A.rhizogenes.

\section{3. Ảnh hưởng của cách thức lây nhiễm vi khuẩn A.rhizogenes đến hiệu quả cảm ứng tạo rễ ở mẫu đậu nành}

Cách thức lây nhiễm vi khuẩn Agrobacterium lên mẫu thực vật có thể cho kết quả cảm ứng tạo 


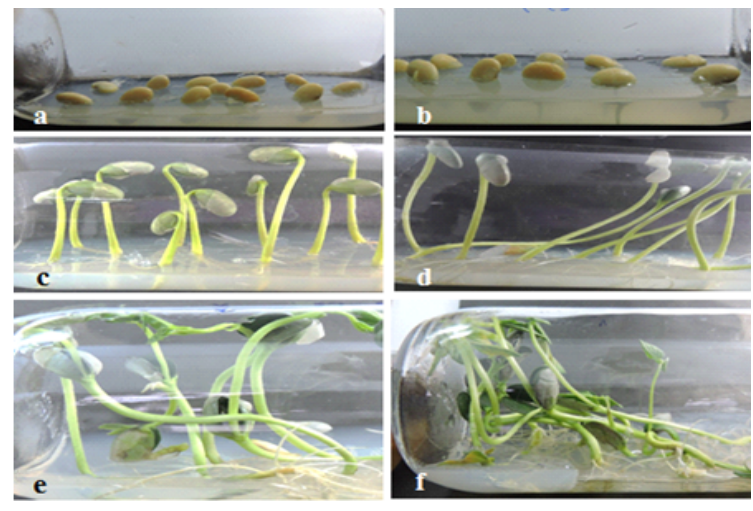

Hình 2. Hạt đậu nành DT84 được gieo trên môi trường B5 ở các ngày tuổi khác nhau.

(a) 0 ngày tuổi; (b) 2 ngày tuổi; (c) 4 ngày tuổi;

(d) 6 ngày tuổi; (e) 8 ngày tuổi; (f) 10 ngày tuổi.

rễ khác nhau. Thí nghiệm này được thực hiện trên đậu nành HLĐN29 và $\mathrm{DT} 84$ nhằm tìm ra cách lây nhiễm phù hợp đối với mẫu lá mầm. Số rễ trung bình và tỉ lệ mẫu tạo rễ được ghi nhận sau khi lây nhiễm A.rhizogenes 14 ngày.

Kết quả ở Bảng 5 cho thấy số rễ trung bình và tỉ lệ mẫu tạo rễ ở nghiệm thức lây nhiễm trực tiếp và ngâm mẫu trong dịch khuẩn ở hai giống đậu nành đều cao hơn so với các nghiệm thức đối chứng (ĐC1 và ĐC2), khác biệt có ý nghĩa về mặt thống kê. Ở giống HLĐN29 và DT84, khi dùng dao nhúng vào dịch khuẩn sau đó tạo vết thương cho tỉ lệ mẫu tạo rễ cao nhất $98 \%$ và $95 \%$. Dù vậy, kết quả này không khác biệt so với phương pháp ngâm mẫu đã tạo vết thương trong dịch khuẩn. Kết quả này tương tự với nghiên cứu của AL-Yozbaki \& ctv. (2015) khi tạo rễ tóc trên đậu nành sử dụng A.rhizogenes R1000. Số rễ trung bình ở hai cách lây nhiễm cũng không khác biệt về mặt thống kê.

\subsection{Khẳng định rễ chuyển gen}

Gen rolC tồn tại trong vùng T-DNA của A.rhizogenes và sẽ tồn tại ở các mẫu rễ chuyển gen. Gen vir $\mathrm{D}$ cũng tồn tại trên Ri plamsid, tuy nhiên do nằm ngoài vùng T-DNA nên gen này không được chuyển vào bộ gen thực vật. DNA của các mẫu rễ giả định chuyển gen được ly trích và thực hiện $\mathrm{PCR}$ để kiểm tra sự hiện diện của gen $\operatorname{rol} \mathrm{C}$ và $\operatorname{vir} \mathrm{D}$ để khẳng định kêt quả chuyển gen.

Gen Golgin 84 là một gen thường trực ở đậu nành và sản phẩm khuếch đại từ gen này có kích
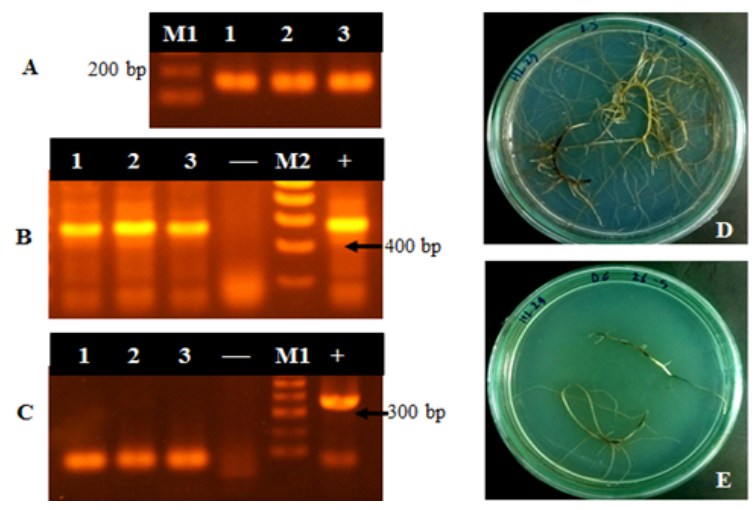

Hình 3. Kết quả kiểm tra sự hiện diện của gen Golgin $84(\mathrm{~A})$, gen $\operatorname{rol} \mathrm{C}(\mathrm{B})$ và gen $\operatorname{vir} \mathrm{D}(\mathrm{C})$ ở các dòng rễ giả định chuyển gen $(1,2,3)$ và rễ không chuyển gen (-). (+) DNA plasmid A.rhizogenes ATCC15834; M1, M2: DNA ladder 100 bp và 1 kb (Bioline); (D) Rễ đậu nành giả định chuyển gen và rễ đối chứng $(\mathrm{E})$.

thước 121 bp (Marcolino-Gomes \& ctv., 2015). Hình $3 \mathrm{~A}$ cho thấy các mẫu DNA ly trích từ các dòng rễ tóc giả định chuyển gen có thể sử dụng cho phản ứng khuếch đại DNA. Các mẫu DNA trên tiếp tục được khuếch đại với cặp primer đặc hiệu cho gen rolC dể kiểm tra kết quả chuyển gen (Hình 3B). Kết quả điện di cho thấy ở các mẫu rễ tóc phân tích đều xuất hiện băng nằm giữa vạch $600 \mathrm{bp}$ và $400 \mathrm{bp}$ của thang DNA chuẩn và tương tự sản phẩm $\mathrm{PCR}$ từ plasmid của A.rhizogenes ATCC15834, phù hợp với kích thước sản phẩm dự kiến là 535 bp. Trong khi đó, khi khuếch đại với cặp primer đặc hiệu cho gen virD, chỉ có mẫu đối chứng dương tạo sản phẩm PCR (438bp) và các mẫu phân tích cho kết quả âm tính (Hình 3C). Kết quả phân tích DNA cho thấy các mẫu rễ kiểm tra đã được chuyển gen từ A.rhizogenes ATCC15834.

\section{Kết Luận}

Nghiên cứu đã xác định được một số điều kiện thích hợp chuyển gen bằng vi khuẩn $A$.rhizogenes trên hai giống đậu nành HLĐN29 và DT84. Lá mầm cảm ứng tạo rễ tốt hơn trụ hạ diệp khi lây nhiễm A.rhizogenes ATCC15834 và ATCC11325. Hiệu quả tạo rễ khi lây nhiễm vi khuẩn trực tiếp và ngâm mẫu trong dịch khuẩn tương đương nhau. Kết quả nghiên cứu có thể ứng dụng trong tạo cây đậu nành chuyển gen nhờ vi khuẩn A.rhizogenes. 


\section{Lời Cảm Ơn}

Nhóm nghiên cứu cảm ơn TS. Nguyễn Như Nhứt đã cung cấp A.rhizogenes chủng C25. Cảm ơn Sở Khoa học Công nghệ Thành phố Hồ Chí Minh, Trung tâm Phát triển Khoa học và Công nghệ Trẻ - Thành Đoàn Thành phố Hồ Chí Minh đã cấp kinh phí cho nghiên cứu. Đề tài thuộc Chương trình Vườn ươm Sáng tạo Khoa học và Công nghệ Trẻ năm 2016.

\section{Tài Liệu Tham Khảo (References)}

AL-Yozbaki, G. S. H., Rasheed, J. H., \& Salih, S. M. (2015). Transformation of Soybean (Glycine max L.) Via GUS-Labeled Agrobacterium rhizogenes R1000. International Journal of Science and Technology 4(6), 267-272.

Cao, D., Hou, W., Song, S., Sun, H., Wu, C., Gao, Y., \& Han, T. (2009). Assessment of conditions affecting Agrobacterium rhizogenes-mediated transformation of soybean. Plant Cell, Tissue and Organ Culture 96(1), 45-52.

Cho, H. J., Farrand, S. K., Noel, G. R., \& Widholm, J. M. (2000). High-efficiency induction of soybean hairy roots and propagation of the soybean cyst nematode. Planta 210(2), 195-204.

Collier, R., Fuchs, B., Walter, N., Kevin, L. W., \& Taylor, C. G. (2005). Ex vitro composite plants: An inexpensive, rapid method for root biology. The Plant Journal 43(4), 449-457.

Fattahi, M., Nazeri V., Torras-Claveria, L., Sefidkon, F., Cusido, R. M., Zamani, Z., \& Palazon, J. (2013). A new biotechnological source of rosmarinic acid and surface flavonoids: hairy root cultures of Dracocephalum kotschyi Boiss. Industrial Crops and Products 50, 256263.

Gamborg, O. L., Miller, R. A., \& Ojima, K.(1968). Nutrient requirement of suspensions cultures of soybean root cells. Experimental Cell Research 50(1), 151-158.

Hayashi, T., Banba, M., Shimoda, Y., Kouchi, H., Hayashi, M., \& Imaizumi-Anraku, H. (2010). A dominant function of CCaMK in intracellular accommodation of bacterial and fungal endosymbionts. The Plant Journal 63(1), 141-154.

Hernandez-Garcia, C. M., Bouchard, R. A., Rushton, P. J., Jones, M. L., Chen, X., Timko, M. P., \& Finer, J. J. (2010). High level transgenic expression of soybean (Glycine max) GmERF and GmUBI gene promoters isolated by a novel promoter analysis pipeline. $B M C$ Plant Biology 10(1), 237.

Homrich, M. S., Wiebke-Strohm, B., Weber, R. L. M., \& Bodanese-Zanettini, M. H. (2012). Soybean genetic transformation: A valuable tool for the functional study of genes and the production of agronomically improved plants. Genetics and Molecular Biology 35(4), 998-1010.
ISAAA (International Service for The Acquisition of Agro-Biotech Applications). 2016. Global Status of Commercialized Biotech/GM Crops: 2016. New York, USA: ISAAA

Karmarkar, S. H, Keshavachandran, R., Nazeem, P. A., \& Girija, D. (2001). Hairy root induction in Adapathiyan (Holostemma adakodien K. Schum.). Journal of Tropical Agriculture 39(12), 102-107.

Kereszt, A., Li, D., Indrasumunar, A., Nguyen, C. D. T, Nontachaiyapoom, S., Kinkema, M., \& Gresshoff, P. M. (2007). Agrobacterium rhizogenes-mediated transformation of soybean to study root biology. Nature protocols 2(4), 948-952.

Krishnan, H. B. (2005). Engineering Soybean for Enhanced Sulfur Amino Acid Content. Crop Science 45(2), 454-461.

Li, J., Todd, T. T., \& Trick, H. N. (2010). Rapid in planta evaluation of root expressed transgenes in chimeric soybean plants. Plant Cell Reports 29(2), 113-123.

Marcolino-Gomes, J., Rodrigues, F. A., FugantiPagliarini, R., Nakayama, T. J., Ribeiro Reis, R., Bou, cas Farias, J. R., \& Nepomuceno, A. (2015). Transcriptome-wide identification of reference genes for expression analysis of soybean responses to drought stress along the day. Plos one 10(9), e013905.

Olhoft, P. M., Bernal, L. M., Grist, L. B., Hill, D. S., Mankin, S. L., Shen, Y., Kalogerakis, M., Wiley, H., Toren, E., Song, H. S., Hillebrand, H., \& Jones, T. (2007). A novel Agrobacterium rhizogenes-mediated transformation method of soybean [Glycine $\max$ (L.) Merrill] using primary-node explants from seedlings. In Vitro Cellular \& Developmental Biology - Plant 43(6), 536-549.

Olhoft, P. M., Flagel, L. X., Donovan, C. M., \& Somers, D. A. (2003). Efficient soybean transformation using hygromycin B selection in the cotyledonary-node method. Planta 216(5), 723-735.

Ozyigit, I. I., Dogan, I., \& Artam Tarhan, E. (2013). Agrobacterium rhizogenes-Mediated Transformation and Its Biotechnological Applications in Crops. In Hakeem, K. R., Ahmad, P., \& Ozturk, M. (Eds.). Crop Improvement: New Approaches and Modern Techniques (ed., 1-48). Massachusetts, USA: Springer.

Savka, M. A., Ravillion, B., Noel, G. R., \& Farrand, S. K. (1990). Induction of hairy root on cultivated soybean genoptypes and their use to propagate soybean cyst nematode. Phytopathology 80(5), 503- 508.

Subramanian, A., Tamayo, P., Mootha, V. K., Mukherjee, S., Ebert, B. L., Gillette, M. A., \& Mesirov, J. P. (2005). Gene set enrichment analysis: A knowledgebased approach for interpreting genome-wide expression profiles. Proceedings of the National Academy of Sciences 102(43), 15545-15550.

Tazeen, S., \& Mirza, B. (2004). Factors affecting Agrobacterium tumefaciens mediated genetic transformation of Vigna radiata (L.). Pakistan journal of botany 36(4), 887-896.

Tran, D. V. (2007). Soybean Glycine max (L) Merr. Ha Noi, Vietnam: Agricultural Publishing House. 